\title{
The Study of Structural Changes in the Industry Debt of the North-Western Economic Area in the Tactical Period
}

\author{
Ivan L. Minin ${ }^{*}$ [ORCID 0000-0003-3302-1767], \\ Dmitry L. Minin 1[ORCID 0000-0002-1690-6646]
}

\author{
${ }^{1}$ Yaroslav-the-Wise Novgorod State University, Veliky Novgorod, Russia \\ Ivan.Minin@novsu.ru
}

\begin{abstract}
The article is aimed at studying the dynamics of industry debt of industries in the domestic currency of the northwestern economic region of the Russian Federation in order to form an objective structure and dynamics of the distribution of overdue credit funds, taking the actions of the Central Bank of the Russian Federation into account. The trend analysis methodology has been highlighted and the author's approach for calculating the interest rate and deflator index has been created, which takes daily fluctuations in the key interest rate into account in order to determine the real cost of borrowed funds when calculating monthly indicators, and also methods of comparative and structural analysis of the following industries debt and individual indicators related to transaction costs and the impact of the financial regulator, the total amount of cash losses are applied: mineral extraction, manufacturing, production and distribution of electricity, gas and water, agriculture, hunting and forestry, construction, transport and communications, wholesale and retail trade; repair of motor vehicles, motorcycles, household goods and personal items, real estate operations, rent and service provision, other activities, for the completion of settlements. The need for implementing measures of state and social support to create prerequisites for the sustainable development of the region's economy through the optimization of monetary policy has been identified, considering the regional development of homogeneous productions and the formation of an optimal distribution of resources in the studied area.
\end{abstract}

Keywords: key interest rate, real debt level, ruble debt, north-western economic region, economic restructuring

\section{INTRODUCTION}

The problem of accounts payable is an important factor hindering the development of the optimal territory economy structure [1]. The formation of a large volume of borrowed funds with enterprises carrying out homogeneous activities entails economic instability of development with a high risk of the industry's transition to depressed development when the conditions of the financial sector of economy change or the production profitability changes [2]. A high degree of lending to industrial complexes of the region can, in the long term, lead the general development of the region to a problem one [3]. Studying the economy of the north-western economic area of Russia will point to the industries with the highest borrowed capital and which, therefore, are a risk group in the event of unfavorable conditions.

\section{MATERIALS AND METHODS}

To achieve the purpose of the study, it is necessary to determine the nature and dynamics of accounts payable in the context of the seasonality of the development of industries in the north-western economic area of Russia (Leningrad, Novgorod and Pskov regions). When carrying out the study, it is required to exclude an anomalous phenomenon in sectoral lending, the federal city of St. Petersburg, which has tendencies that are characteristic not for even territorial development in the field of financial activities, but for the development of the financial sector of a large metropolitan area, which can skew 
the final result. The study examines the debt development in various industries for the period from September 2021 to December 2022, taking the key rate of the Central Bank of the Russian Federation into account [4].

The questions of this study are:

- studying the trends in the dynamics of changes in accounts payable in the sectors of the north-western economic area (except for the federal city of St. Petersburg) for the period from September 2021 to December 2022;

- studying the trends in the dynamics of changes in accounts payable in the industries of the north-western economic area for the period from September 2021 to December 2022 using 2017 base prices;

- identifying industries in the north-western economic area with a high share of real debt and loss of financial resources in the form of a natural inflation rate and the possibility of a problematic development.

The purpose of the study is to determine the need for additional financial support for individual industries in the north-western economic area for the tactical period, considering the development of the key rate of the Central Bank of the Russian Federation to optimize the financial stability of homogeneous industries in the study area and to prevent the emergence of structurally depressed industries and problematic economy development in whole.

To achieve the purpose of the study, the methodology of trend analysis has been applied, taking the determination coefficient into account, a comparative analysis has been carried out with the reduction of indicators to the prices of the first sampling period - base prices - taking the change in the key rate of the Central Bank of the Russian Federation into account, a structural industry analysis of debt has been applied as well.

To form the sample, data from statistical bulletins of the Central Bank of the Russian Federation has been used by the ratio of credit dept provided to legal entities - residents and individual entrepreneurs - in rubles, by type of economic activity and certain areas of using funds in rubles with a volume of 50 indicators in a direct time sequence with a 1 month time interval, starting from July 2017, and forming trends in current prices of 7 homogeneous other industries by transaction costs of lending services. The classification of directions has remained unchanged since 2007. A trend analysis in current prices for each indicator has been applied to determine the nature of the dynamics of the region's production debts development without taking the interest rate into account (1):

$$
Y_{3}(x)=\sum_{n=1}^{J}(Y j), \text { mln.rub. }
$$

where: $Y j$ - the function of the nominal debt of the $j$ th homogeneous production and transaction costs of settlements according to the classification of the Central Bank of the Russian Federation, mln rubles; $\mathrm{x}$ - an independent temporary variable used in the period $[1 ; 66]$ of the key interest rate for each month (2):

$$
R i(x)=\frac{\sum_{n=1}^{i}(K i) * f i}{T i}, \%
$$

where: $\mathrm{Ki}$ - the daily value of the annual key interest rate, \%; fi - the number of days with a certain key interest rate value of the $\mathrm{i}$-th month, days; $\mathrm{Ti}-$ the number of days in a year.

Based on the monthly key interest rate, the deflator index values for each study period have been determined ( 3 ):

$$
\operatorname{Idi}(x)=\operatorname{Id}(i-1)\left(1+\frac{R(i-1)}{100}\right), \text { shares }
$$

where: $\mathrm{R}$ (i-1) - a monthly percentage of the key interest rate of the previous month, \%; Id (i-1) - a monthly deflator index for the previous month, shares.

Further, the real amount of debt has been determined using the index to determine the debt at basic prices of July 2017 (4):

$$
Y \operatorname{pз}(x)=\sum_{n=1}^{J}(Y j) / I d i, m l n . r u b .
$$

The total volume of debt cash losses due to the presence of the key interest rate value of the Central Bank of the Russian Federation different from $0 \%$ is expressed and a trend of the phenomenon is built (5):

$$
L(x)=Y_{3}-Y \mathrm{p} 3, m \ln . r u b .
$$

Formula (1) has been transformed using the sum of real debt in prices of the base period of homogeneous production and transaction costs of settlements, as well as the total amount of cash losses (6):

$$
Y_{3}(x)=\sum_{n=1}^{J}(Y \mathrm{p} 3 j+L j), \text { mln.rub. }
$$

Forecasting has been carried out using the trends of nominal and real value of business debt for the period up to December 2022 (for 16 periods) and the shares of debt of homogeneous industries have been 
revealed. 5 industries with the largest share of debt during the forecasting period have been selected for the study.

\section{RESULTS}

Having studied the trends in the debt development, the main trends in the change in borrowed funds of homogeneous industries, which are represented by functions with a polynomial and exponential nature, have been identified.

The nonlinear nature of the indicator under consideration has indicated the instability of the debt development, associated, first of all, with the general market environment.

The trends in homogeneous industries, as well as the general trend in the debt development have been identified (7, 7.1-7.10), which is a combination of the following functions:

$$
\begin{aligned}
& Y_{3}(x)=-0.025 x^{4}+4.5887 x^{3}-18.7265 x^{2}-6616.317 x+1303.5 * e^{0.8518 x}+361930, R^{2} \\
& =74.32588, \mathrm{mln} \cdot \mathrm{rub} .(7) \\
& \text { Yдпи }=6.2556 * x^{2}-422.23 x+7095.7, R^{2}=0.7248, \quad m \ln . r u b .(7.1) \\
& \text { Үоп }=184.33 * x^{2}-6675.9 x+174565, R^{2}=0.7867, \text { mln.rub. (7.2) } \\
& \text { Үпрэгв }=-0.0004 x^{4}-0.6629 x^{3}+69.045 x^{2}-1833.2 \mathrm{x}+21860, R^{2}=0.8491, m \ln . r u b .(7.3) \\
& \text { Үсхолх }=0.6482 x^{2}+179.41 x+45165, R^{2}=0.4317, \text { mln.rub. (7.4) } \\
& \mathrm{Yc}=12.969 * x^{2}-921,84 \mathrm{x}+37446, R^{2}=0.7577, \text { mln.rub. (7.5) } \\
& \mathrm{Y} m c=1303.5 * e^{0.8518 x}, R^{2}=0.8485, \text { mln.rub. (7.6) } \\
& \text { Yopm }=-18.243 * x^{2}+1175.8 x+21268, \quad R^{2}=0.7411, \text { mln.rub. (7.7) } \\
& \text { Үони }=-0.0246 x^{4}+5.2516 x^{3}-286.99 x^{2}+4975.8 \mathrm{x}+9292.4, R^{2}=0.6831, \text { mln.rub. (7.8) } \\
& \text { Yno }=13.496 * x^{2}-988.16 x+21338, R^{2}=0.7787, \text { mln.rub. (7.9) } \\
& Y p=-0.2373 * x^{2}+29.193 x+1998, R^{2}=0.4988, \text { mln.rub. (7.10) }
\end{aligned}
$$

where: $Y_{\text {дпи }}, Y_{\text {оп }}, Y_{\text {прэгв }}, Y_{\text {схолк }}, Y_{c}, Y_{\text {тс }}, Y_{\text {орт }}, Y_{\text {они }}, Y_{\text {по }}, Y_{p},-$ the nominal trends in loan debt (mineral extraction, manufacturing, production and distribution of electricity, gas and water, agriculture, hunting and forestry, construction, transport and communications, wholesale and retail trade; repair of vehicles, motorcycles, household goods and personal items, operations with real estate, rent and provision of services, other activities, for the completion of settlements) of the north-western economic area, million rubles; $\mathrm{X}$ - an independent temporary variable used in the period from July 2017 to December 2022 and complying with the $\mathrm{X} \in$ condition $[1 ; 66]$.

\section{A number of trends have been identified.}

1) A fourth-degree polynomial function indicating the presence of 3 extreme trend values, $i$. e. the presence of a number of phenomena associated with a significant change in the characteristics of the indicator with nonlinear acceleration. The production and distribution of electricity, gas and water and transactions with real estate have an unstable nature of development, and within the framework of the study, it is possible to observe the full development cycle of changes in homogeneous industries debt. These industries relate to the implementing inelastic benefits and are more dependent on the general level of well-being of the region households and business profitability.

2) A second-degree polynomial function indicates the instability of development and the presence of at least one extreme point and a change in the development trend. Most industries have such a value and are inherently non-linear with a linear acceleration in the development of such a phenomenon as a crisis. These are mineral extraction, manufacturing, agriculture, hunting and forestry, construction and other industries which indicates a change in the development trend from debt reduction to its new growth. Industries that reduce the amount of debt or funds spent on the lending itself have been identified. These are wholesale and retail trade, repair of motor vehicles, motorcycles, household goods and personal items and for the completion of settlements.

3) The exponential function illustrates high rates of debt growth, which may indicate serious crisis phenomena in the industry and the need to implement significant measures to support it, taken not only by financial and self-regulatory organizations, but also by public entities. Transport and communications have this trend in the debt development so that the industry needs to be provided with preferential loans, state and municipal guarantees. 
It is also necessary to take the regulatory function of the Central Bank of the Russian Federation, into account. Therefore, it is necessary to reduce the indicators to the base prices at the beginning of the study and to highlight a separate function of the total volume of cash losses to determine the real cost of borrowed funds at any given time. When introducing a new trend, the value of other trends will also change $(8,8.1-8.11)$, but their nature will remain unchanged, due to the unity of the interest rate for banks for lending to any commercial activity:

$$
\begin{aligned}
& Y_{3}(x)=-0.0216 x^{4}+3.853 x^{3}+45.845 x^{2}-5423.91 x+1292.2 * e^{0,0482 x}+449548.3, R^{2}= \\
& 74.34990, \text { mln.rub. (8) }
\end{aligned}
$$

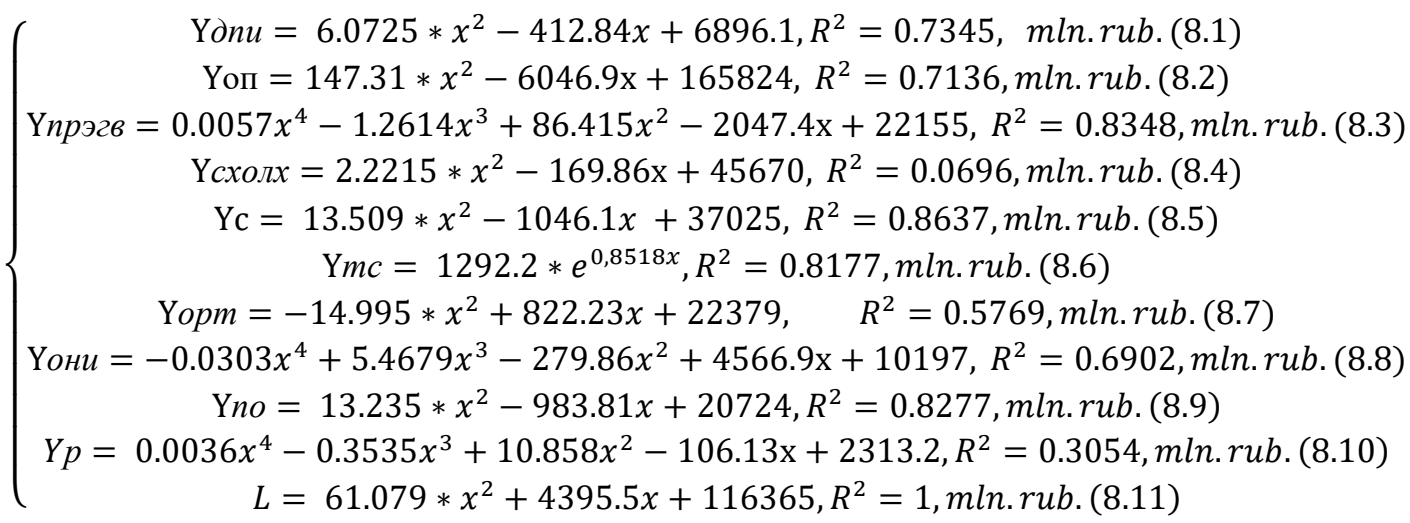

where: $\mathrm{Y}_{\text {дпир }}, \mathrm{Y}_{\text {опр }}, \mathrm{Y}_{\text {прэгвр }}, \mathrm{Y}_{\text {схолкр }}, \mathrm{Y}_{\text {ср }}, \mathrm{Y}_{\text {тср }}, \mathrm{Y}_{\text {ортр }}, \mathrm{Y}_{\text {онир }}, \mathrm{Y}_{\text {пор }}, \mathrm{Y}_{\mathrm{pp}}, \mathrm{L}$ - real trends in loan debt (mineral extraction, manufacturing, production and distribution of electricity, gas and water, agriculture, hunting and forestry, construction, transport and communications, wholesale and retail trade; repair of vehicles, motorcycles, household goods and personal items, operations with real estate, rent and provision of services, other activities, for the completion of settlements, the total amount of cash losses) of the north-western economic area, million rubles; X - an independent temporary variable used in the period from July 2017 to December 2022 and complying with the $\mathrm{X} \in$ condition $[1 ; 66]$.

The nature of the phenomenon development remained unchanged, except for a quantitative decrease in the function indicators, therefore, changes in the growth rate. The instability of the calculation function has increased, i. e. lending transaction costs have become less stable in real money terms, with a more frequent trend reversal. This trend indicates how much the efficiency of settlements development and the whole banking system functioning changes by the redistribution of financial resources in the economy.

Due to a non-zero rate of the Central Bank of the Russian Federation, the fund loss function indicates a certain amount of funds that are used free of charge to ensure the net public goods of the economy and profit made by the financial regulator.

The non-linear indicator growth not only reduces the real loan value, but also leads to a depreciation of the ruble against other currencies, which entails difficulties in attracting foreign investment for restructuring and modernizing the economy.

It is also important to identify the industries that have the main share of debt and are the main consumers of borrowed funds for the tactical period from September 2021 to December 2022 (Table 1).

Table 1. Forecasted values of the debt structure in domestic currency of homogeneous industries in the north-

\begin{tabular}{|c|c|c|c|c|c|c|c|}
\hline Indicator & 09.21 & 12.21 & 03.22 & 06.22 & 09.22 & 12.22 & AVR \\
\hline Mineral extraction & 0.31 & 0.40 & 0.49 & 0.57 & 0.65 & 0.72 & 0.52 \\
\hline Manufacturing & 46.20 & 46.73 & 47.16 & 47.51 & 47.79 & 48.02 & 47.26 \\
\hline Production and distribution of electricity, gas and water & 2.64 & 2.33 & 2.01 & 1.68 & 1.36 & 1.05 & 1.85 \\
\hline Agriculture, hunting and forestry & 7.97 & 7.23 & 6.57 & 5.98 & 5.46 & 5.00 & 6.35 \\
\hline Construction & 3.61 & 3.46 & 3.35 & 3.26 & 3.20 & 3.15 & 3.33 \\
\hline Transport and communications & 2.94 & 3.08 & 3.23 & 3.38 & 3.55 & 3.73 & 3.32 \\
\hline $\begin{array}{l}\text { Wholesale and retail trade; repair of motor vehicles, } \\
\text { motorcycles, household goods and personal items }\end{array}$ & 4.86 & 4.01 & 3.23 & 2.53 & 1.90 & 1.33 & 2.96 \\
\hline Real estate operations, rent and service provision & 6.82 & 7.66 & 8.50 & 9.28 & 9.97 & 10.54 & 8.81 \\
\hline
\end{tabular}
western economic area of Russia for the period from September 2021 to December 2022, shares 


\begin{tabular}{|l|c|c|c|c|c|c|c|}
\hline Other activities & 0.96 & 1.08 & 1.20 & 1.33 & 1.46 & 1.58 & 1.27 \\
\hline For the completion of settlements & 0.50 & 0.56 & 0.64 & 0.76 & 0.91 & 1.09 & 0.73 \\
\hline The total amount of cash losses & 23.20 & 23.46 & 23.62 & 23.72 & 23.77 & 23.79 & 23.61 \\
\hline
\end{tabular}

Source: Compiled by the authors based on data [4]

Manufacturing industries have the largest share of loans in the forecasting period [5].

\section{DISCUSSION}

A problematic situation is observed in the provision of services for transactions with real estate, indicating an increase in the share of debt, which may lead to an investment crisis in the region. Agriculture is an industry that is highly dependent on the financial market due to the peculiarities of the production cycle but owing to the development and state support of agricultural producers, the level of debt is decreasing [6].

Owing to the implementation of economic support measures, the level of debt in construction is being reduced. The most difficult situation remains in the field of transport and communications - there is an increase in debt due to unfavorable macroeconomic conditions for global transportation, taking the transitional stage of the region's economy development into account.

The problem of an increase in the share of settlements transaction costs indicates the need to reform the institutions for the redistribution of the results of productive labour and the formation of a more efficient and affordable credit system. Cash losses are shown as of July 2017 (start of survey sample) and indicate that a quarter of the debt was lost during five years due to reallocation of funds by the financial regulator in order to ensure currency stability and the consumption of public goods.

\section{CONCLUSION}

The problem of debt of homogeneous industries is one of the most important one when studying the possibilities and nature of restructuring the region, as well as ensuring the sustainability of economic development as a whole [7].

The north-western economic area of Russia has an uneven multidirectional debt growth, but the most difficult situation is observed in manufacturing industries due to the fact that the industry owns about half of all overdue debt with continuing nonlinear uniformly accelerated growth, which, under unfavorable conditions of the structural crisis, will lead to the impossibility of using intra-industry resources for the implementation of restructuring
[8]. The growth of debt load on real estate transactions and the high growth in lending to industrial production indicate the possibility of a financial bubble formation with the shutdown of modern production facilities due to the massive bankruptcy of the industry enterprises. Transport and communications is a crisis production due to the existing restrictions and the inability to restore the financial potential for reorganizing the services provided, including its own infrastructure, without using direct government assistance at the moment. The most favorable situation is observed in those industries that are least affected by negative general economic trends and have extensive government support programs with inelastic demand: agriculture, trade and construction [9].

The financial institutions of the region also need significant reforming due to the high transaction costs of using borrowed funds, which imposes an additional burden on all sectoral industries and is a constraining factor in the economy development [10]. The growth in the loss of funds from the use of the interest rate by the financial regulator indicates an increase in social expenditures and public administration expenditures, indicating a clear severity of the crisis in the country's economy [11]. To ensure financial stability, it is important to take measures of state regulation and tightening the financial and credit policy along with expanding measures of public-private partnership with the direct participation of civil society institutions [12] in order to create a favourable and stable situation in the operational and financial cycle of industrial production and participate in the reform of financial regulation instruments and intersectoral reallocation of funds.

\section{AUTHORS' CONTRIBUTIONS}

The authors made an equal contribution to the study: collection and analysis of material; definition of goals and objectives, research methods; formulation and scientific substantiation of conclusions, registration of key research results in the form of an article.

\section{REFERENCES}

[1] A. Saffer, "Value-Added Theory", The International Encyclopedia of Strategic 
Communication, 2018, pp. 1-10. DOI: 10.1002/9781119010722.iesc0197

[2] S. Agarwala, R. Hauswald, "Information disclosure and the choice between arm's-length and inside debt", Journal of Monetary Economics, 2021, vol. 117, pp. 1008-1022. DOI: $10.1016 /$ j.jmoneco.2020.08.001

[3] N.A. Kanischeva, M.V. Kivarina, O.S. Kukushina, E.A. Okomina, "Methodological aspects of the analysis and assessment of the creditworthiness of enterprises in various areas of the agroindustrial complex and the practice of their application", In Proceedings of IOP Conference Series: Earth and Environmental science: Innovative Technologies in Agroindustrial, Forestry and Chemical Complexes and Environmental Management, 2021, p. 012041. DOI: $10.1088 / 1755-1315 / 852 / 1 / 012041$

[4] Federal State Statistics Service, 2021. (In Russ.). Retrieved from: http://www.gks.ru

[5] A.B. Petrukhin, Yu.A. Dmitriev, M.M. Omarov, D.L. Minin, "Investment potential and forecast of development of branches of light and textile industry of the Russian federation", Proceedings of Higher Education Institutions. Textile Industry Technology, 2020, vol. 6(390), pp. 26-31. (In Russ.).

[6] O.N. Vinogradova, "Differentiation of production of the regional agro-industrial complex as a factor in ensuring the economic and social stability of a territory", In Proceedings of IOP Conference Series: Earth and Environmental science: Innovative Technologies in Agroindustrial, Forestry and Chemical Complexes and Environmental
Management, 2021. p. 012109. DOI: $10.1088 / 1755-1315 / 852 / 1 / 012109$

[7] V. Mironov, L. Konovalova, "Structural changes and economic growth in the world economy and Russia", Russian Journal of Economics, 2019, vol. 5(1), pp. 1-26. DOI: 10.32609/j.ruje.5.35233

[8] M. Anokhina, "Parameters of the strategy for managing the economic growth of agricultural production in Russia", Agricultural Economics - Czech, 2020, vol. 66, pp. 140-148. DOI: 10.17221/255/2019-AGRICECON

[9] E.S. Minina, I.L. Minin, D.L Minin, "Analysis of the Gross Agricultural Product in the Northwestern Federal District", In Proceedings of IOP conference series: earth and environmental science: Innovative Technologies in Agroindustrial, Forestry and Chemical Complexes and Environmental Management, 2021 , p. 012069. DOI: 10.1088/1755$1315 / 852 / 1 / 012069$

[10] A. Abdimomynova, "Development factors of export potential of the region: Capabilities in minerals and infrastructure sector", Academy of Strategic Management Journal, 2018, vol. 17(3), pp. 1-11.

[11]N. Hammar, Y. Belarbi, "R\&D, innovation and productivity relationships: Evidence from threshold panel model", International Journal of Innovation Studies, 2021, vol. 5(3), pp. 113126. DOI: $10.1016 /$ j.ijis.2021.06.002

[12]F. Mammadova, M. Mammadov, A. Kariuk, E. Mammadov, "Economic Reforms and Development Strategies as Providing Sustainable Development", Lecture Notes in Civil Engineering, 2021, vol. 181, pp. 669-676. 